\title{
ASR OF RICE HUSK AND THE POTENTIAL USE OF RHA TO MITIGATE ASR IN CEMENT COMPOSITE
}

\author{
Reaksi Alkali Silika Agregat Sekam Padi dan Potensi Abu Sekam Padi untuk Mengatasi Reaksi Alkali \\ Silika dalam Pembuatan Komposit Semen
}

Bakri, Djamal Sanusi, and Musrizal Muin

\begin{abstract}
ABSTRAK
Penelitian ini bertujuan untuk mengetahui potensi reaksi alkali silika (ASR) pada sekam padi. Pembuatan contoh uji Mortar Bar didasarkan pada ASTM C 1260 yang dikenal sebagai "Accelerated Mortar Bar Test". Sekam padi yang telah dibersihkan dan dikeringkan kemudian digiling dengan menggunakan blender selama 3 menit untuk menghasilkan partikel sekam padi lolos ayakan 10 mesh. Pembuatan Mortar Bar dilakukan dengan mencampur sekam padi, semen, dan kapur yang dicetak pada molder kubus ukuran 25 x $25 \times 285 \mathrm{~mm}$. Rasio komposisi campuran sekam padi : \{(semen : kapur) $\}$ terdiri atas 6 komposisi campuran $(A, B, C, D, E$, dan F) dengan rasio 30 dan $40 \%:\{(100: 0),(72: 25),(50: 50)\}$ berdasarkan berat semen + kapur. Persentase pertambahan panjang Mortar Bar diukur setelah contoh uji yang direndam pada larutan $\mathrm{NaOH} 1 \mathrm{~N}$ disimpan dalam tanur pada suhu $80^{\circ} \mathrm{C}$ selama 16 hari. Hasil penelitian ini menunjukkan bahwa ASR contoh uji Mortar Bar pada semua komposisi campuran tergolong potensial merusak dan sekam padi tergolong agregat reaktif.
\end{abstract}

Kata kunci:

\section{INTRODUCTION}

Alkali Silica Reaction (ASR) results from the reaction of the alkalis in the cement with the siliceous components of certain aggregates. This reaction produces a gel that significantly expands in the presence of moisture, causing cracking of the surrounding cement matrix and the development of an irregular cracking. ASR was first reported in the late of 1930 and now become very famous in the field of construction because this reaction causes damage to concrete structures. The reaction between the alkaline pore solution and silica minerals will produce alkalisilica gels that take up water and expand in moist condition. Special attention has been focused to ASR during the last 10 to 20 years because of the extensive damage to the structure and characteristics changes of concrete. ASR occurs very quickly but the development of cracks can happen for several years and will be visible after 5 to 10 years later. Crack will facilitate the water enter into the cement paste so that the ASR will continue and the cracks will occur after a few years later.

The presence of reactive aggregates or another reactive silica source in concrete is necessary for ASR to occur. The term reactive refers to aggregates that tend to decompose under exposure to the highly alkaline pore solution in concrete or other cement composites and subsequently react with the alkalis (sodium and potassium) to form an expansive ASR gel. The presence of sufficient alkalis is another required ingredient for ASR. While Portland cement is considered the main contributor of alkalis, under certain conditions, other materials may provide additional alkalis that are available to the reaction. ASR can principally only happen because of the 3 components, namely silica in the aggregate, high alkali Portland cement and other materials mixed with cement, and water (high humidity). If one of these components is omitted then the ASR can be prevented. Aggregates containing reactive silica found in the arenite, argillite, chert, flint, gneiss, granite, greywacke, hornfels, quartz, arenite, quartzite sandstone, shale, silicified carbonate, and siltstone.

Amount of alkali in Portland cement which is denoted as $\mathrm{Na}_{2} \mathrm{Oe}$ (equivalent of soda) in percent is calculated based on a formula $\mathrm{Na}_{2} \mathrm{Oeq}=\mathrm{Na}_{2} \mathrm{O}$ $+\mathrm{Na}_{2} \mathrm{O}$ 0658. Although the percentage of alkalis in Portland cement is relatively low (in the range of 0.2 to 1.1 percent) in comparison to other oxides 
or compounds, the bulk of the alkalis ultimately resides in the pore solution of concrete, and it is the associated hydroxyl (OH-) concentration (necessary to maintain charge balance) that produces the inherent high $\mathrm{pH}$ in the pore solution (i.e., 13.2 to 14.0). The main source of hydroxyl ions $(\mathrm{OH}-)$ in cement paste is derived from calcium hydroxide produced by cement hydration process. The more calcium hydroxide resulting from hydration process and the higher amount of alkali in the cement, the higher the alkalinity of cement paste to occur.

Damage to concrete or other cement composite only occurs at a high alkaline content of Portland cement that has more than $1 \% \mathrm{Na}_{2} \mathrm{O}$ eq. It has been stated for many years that expansion resulting from the ASR reaction will not occur when the alkali content of the Portland cement is below 0.6 percent $\mathrm{Na}_{2} \mathrm{Oeq}$. To determine safe levels of alkaline pore solution in cement paste only the alkali contained in the Portland cement to be reckoned with, while the alkali derived from other materials which can increase the total alkali cement paste is not considered. However, Freitag, et al. (2003) argued that it is now recognized that limiting the alkali content of Portland cement is not, by itself, an effective way of preventing ASRinduced damage, because this approach does not control the total alkali content of the concrete mixture.

At present the use of lightweight aggregate originating from agricultural by-product (natural fibers) in the manufacture of lightweight cement composite began to be paid attention. Lightweight composite cement using agricultural wastes in form of natural fibers can be implemented as green building materials that reduce environmental impacts in the construction sector. One of the most potential agricultural wastes to be considered as an aggregate for composite cement is rice husk. However, due to its highly silica content, rice husk mixed with cement probably will generate alkali silica reaction that can cause cracks in cement composite for long-term usage. Therefore, before using rice husk as aggregate for composite cement, it is first need to understand its reactivity in alkali silica reaction by using Mortar Bar Test.

\section{MATERIALS AND METHODS}

The main materials used in the Mortar Bar Test were Portland cement type I, lime, and rice husk locally available in Makassar. Other materials used were distilled water and $\mathrm{NaOH}$. The equipment used is the measuring cup, test tube, digital balance, thermometer, hygrometer and calipper, rectangular molder $25 \times 25 \times 285$ $\mathrm{mm}$, basins, buckets, and plastic bags, sieves, mixer, and computer. This research was conducted in January 2010 until February 2009 at the Laboratory of Wood Science, Hasanuddin University.

Preparation of sample testing were based on ASTM C 1260 method known as "Accelerated Mortar Bar Test" as practiced by Rangaraju (2007). Rice husk was washed with water to separate with dirt. The washed rice husk soaked in water for 1 day and then dried until it reaches the air dried condition. The dried rice husk milled in a blender for 3 minutes and then sieved in 10 mesh sieve and stored in sealed plastic bags prior to use. Preparation of Mortar Bar test samples made by mixing rice husk, Portland cement Type $\mathrm{I}$, and lime with the ratio of mixture composition namely (A) $30 \%:(100: 0)$, (B) $40 \%:(100: 0)$, (C) $30 \%:$ (75:25), (D) $40 \%:$ (75:25), (E) $30 \%$ : ( $50: 50)$, and (F) $40 \%:(50: 50)$. The number of Mortar Bar samples of each ratio were 3 samples that were molded in $25 \times 25 \times 285 \mathrm{~mm}$ rectangular molder.

Mortar Bar samples stored for 24 hours in a humid place. After 24 hours storage, Mortar Bars removed from the molder and immersed into a container filled with water. Mortar Bars in a container filled with water then placed into the oven at a temperature of $80^{\circ} \mathrm{C}$ for 24 hours. The initial length of Mortar Bars were measured after being stored for 24 hours in oven. After measuring the initial length, Mortar Bars soaked in $1 \mathrm{~N}$ $\mathrm{NaOH}$ and placed again in oven at a temperature of $80^{\circ} \mathrm{C}$ for 16 days. Measurement change in length was done periodically during the storage.

\section{RESULT AND DISCUSSION}

\section{Mortar Bar Test}

The average percentage of change in length of Mortar Bar can be seen in Figure 1. The average percentage of change in length of Mortar Bar from the highest to the lowest was respectively $0.19,0.18,0.17,0.15,0.13$, and $0.12 \%$ occurred in mixture composition of $B, A, F$, $E, D$, and C. Classification criteria of alkali silica 


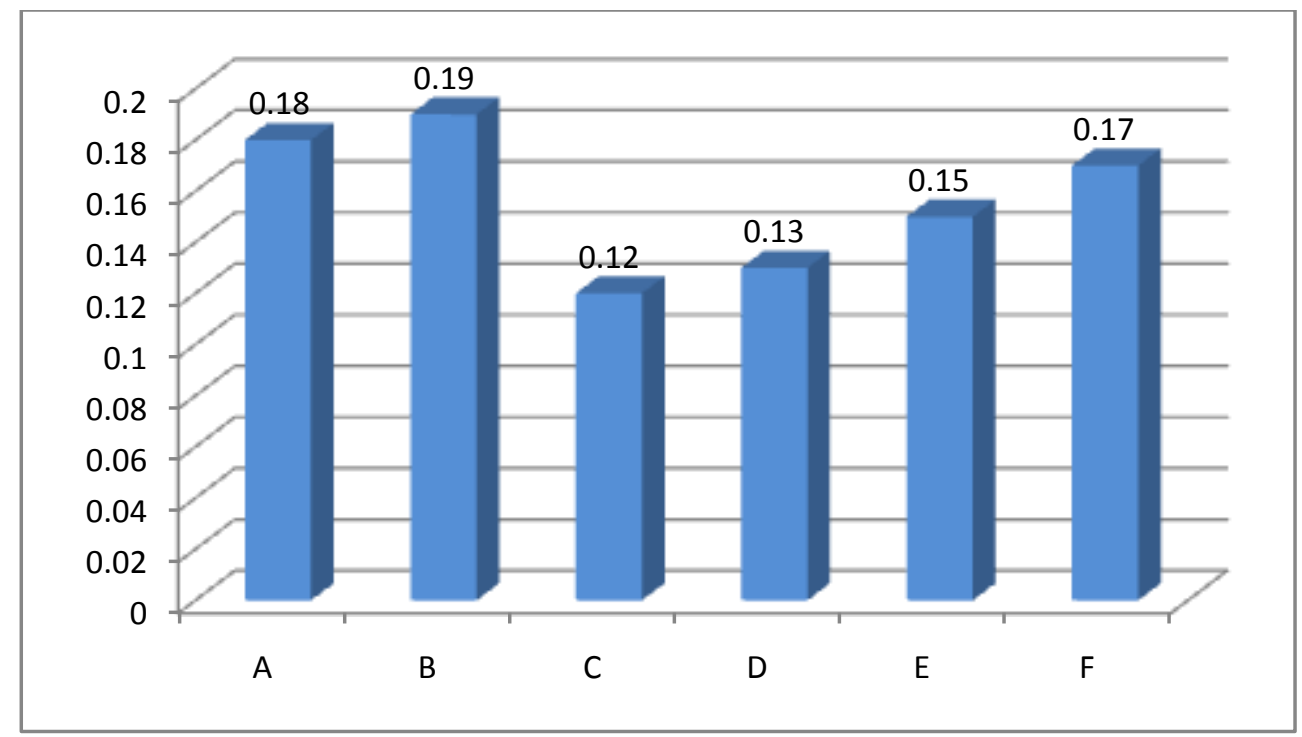

Figure 1. Average Percentage of Change in Length of Mortar Bar

activity in ASTM C 1260 based on the length change percentage that is $<0.10 \%$ categorized not to destroy, 0.10 to $0.20 \%$ categorized potential to damage and $>0.20 \%$ categorized to damage (Folliard, et al. , 2006). Based on the criteria of ASTM C 1260, the mixture composition of $A, B, C, D, E$, and $F$ produce alkali silica reaction pertained potential to damage.

The Mortar Bar test result of alkali silica reactivity of rice husk showed that although type I Portland cement used in this study had a low alkaline because of its equivalent soda $\left(\mathrm{Na}_{2} \mathrm{Oe}\right)$ value smaller than $0.6 \%$, it still produced ASR. This proved that the minimum level of alkaline of Portland cement tipe I below $0.6 \%$ does not guarantee no occurrence of alkali silica reaction. The test result also showed that increasing the rice husk percentage will increase the length of Mortar Bars at the same ratio indicating that the rice husk aggregate has the potential reactivity to produce alkali silica reaction.

Addition of rice husk percentage will increase probability of alkali silica reaction to occur because of the increasing silica content in the Mortar Bar. The test results showed none of the length change percentage of Mortar Bars produced greater than $0.20 \%$. This is because the soda equivalent value $\left(\mathrm{Na}_{2} \mathrm{Oe}\right)$ Portland cement type I used has value smaller than $0.6 \%$. Low equivalent soda value will not produce the optimum alkali silica reaction. Nevertheless, due to large $\mathrm{C}_{3} \mathrm{~S} / \mathrm{C}_{2} \mathrm{~S}$ ratio (2.36) of Portland cement type I, so the formation of $\mathrm{Ca}(\mathrm{OH})_{2}$ will become greater that it can raise the $\mathrm{pH}$ of the pore solution.

Increasing $\mathrm{pH}$ value of the hydroxyl ions of $\mathrm{Ca}(\mathrm{OH})_{2}$ in the pores solution will allow the occurrence of alkali silica reaction. Similarly, the addition of lime in Mortar Bars will increase the alkaline nature of cement. The test results also indicate that the addition of lime produce a lower length change percentage of Mortar Bar. The lower length change percentage of Mortar Bar by the addition of lime caused by $\mathrm{Ca}^{2+}$ ions from $\mathrm{Ca}(\mathrm{OH})_{2}$ were increasing rapidly. If these $\mathrm{Ca}^{2+}$ ions joined with silicic acid gel $\left(\mathrm{H}_{2} \mathrm{SiO}_{4}\right)^{2-}$ then the number of gels (rigid and do not expand) will increase. Silica $\left(\mathrm{SiO}_{2}\right)$, which are mostly located on the surface of rice husk aggregate, when dealing with hydroxyl ions $\left(\mathrm{OH}^{-}\right)$derived from $\mathrm{KOH}$ and $\mathrm{NaOH}$ will form silicic acid gel $\left(\mathrm{H}_{2} \mathrm{SiO}_{4}\right)^{2}$. The more hydroxyl ions into contact with silica the more silica gel is also formed. To balance this charge of gel ion, the negative ions of silicic acid will attract positive ions from the $\mathrm{Ca}^{2+}, \mathrm{Na}^{+}$, or $\mathrm{K}^{+}$. If the amount of $\mathrm{Ca}(\mathrm{OH})_{2}$ more and more as a result of the hydration of cement and lime, the silicic acid will attract more $\mathrm{Ca}^{2+}$ ions which will further increase the amount of compound formation $\mathrm{CaH}_{2} \mathrm{SiO}_{4}$. $\mathrm{CaH}_{2} \mathrm{SiO}_{4}$ compound is a compound that resembles the calcium silicate hydrate compound that is rigid, not reactive, and do not expand. Conversely if the amount of $\mathrm{Ca}(\mathrm{OH})_{2}$ is less then the silicic acid will attract ions 
of $\mathrm{Na}^{+}$or $\mathrm{K}^{+}$, which in turn will form compounds $\mathrm{K}_{2} \mathrm{H}_{2} \mathrm{SiO}_{4}$ or $\mathrm{Na}_{2} \mathrm{H}_{2} \mathrm{SiO}_{4}$. These compounds remains in a form of viscous gel so that if absorbing the water then the gel will swell. This condition occurs more frequently on the mixtures composition of $A$ and $B$ because the composition of this mixture does not contain lime. Alkali silica gel can absorb water through osmosis process to produce development. Cement paste is in the process of osmosis membrane that allows water, alkali, and the hydroxyl ions diffuse, and generate pressure on cement paste resulting in internal stresses.

The role of water in the alkali silica reaction is very important since it is much more said that the ASR gel must be in a solid form with the absence of water. Therefore, the magnitude of the length change percentage of Mortar Bar is also influenced by water absorption in Mortar Bars. Absorption of water by Mortar Bars strongly influenced by the amount of rice husks in the Mortar Bar. Rice husk is a porous material that can absorb water in significant amounts. The greater the amount of rice husk, the greater the amount of water absorbed by the Mortar Bars. This is evidenced by the greater change percentage in length of Mortar Bars at the $40 \%$ of rice husk compared to that of $30 \%$ of rice husk. Rice husk demonstrating high suction potential are strongly hydrophilic so it can rapidly imbibe water. This is very perilous since it allows water to more easily flow into and through the cement matrix to form an ASR.

Solid ASR gel has the capacity to imbibe water molecules which causes the extensive swelling of the gel and makes the gel a fluid, especially those ASR gels attracting $\mathrm{K}^{+}$ions or $\mathrm{Na}^{+}$ions. Reaction product gel can swell due to its typical property in colloidal system. The swelling must generate pressure in the gel since the ASR gel is inhibited in the pores of cement mixture and that pressure will limit the intake of water by the gel. Expansion of the ASR gel can be partly accomodated by its removal into the capillary pores in the hardened cement paste located on the particle surface. The development of pressure will occur when cement mixture resists the swelling. The pressure boost is considered to inhibit water imbibitions and to cause part of the gel to diffuse into the adjacent capillary pores and cracks in the composite.

Strongly hydrophilic of rice husk not only influence the occurrence of ASR but also may affect the workability of Mortar Bar to harden completely. The amount of water added to the cement mixture must be adjusted for the moisture conditions of the aggregates in order to accurately meet the water requirement of the mix design. Dry rice husk particles will absorb much more water from the cement mixture and can inhibit the hydration process due to the lack of water to complete the reaction of hydration. Aggregates with high absorption values often results in large variations in composite quality because moisture content of aggregates is difficult to control. Composites will be loose their workability and more rapidly become rigid before the reaction of hydration completely done because strongly hydrophilic aggregates will absorb water from the cement mixture.

\section{The Role of RHA as SCM to Mitigate ASR (Research Overview)}

RHA produced from burning rice husk at a temperature of 400 - $500{ }^{\circ} \mathrm{C}$ will become amorphous silica and in the temperature greater than $1000{ }^{\circ} \mathrm{C}$ will become crystalline silica. Silica content in RHA ranges between 92 - 95\%, very porous and lightweight, and has a very large surface area. Conversion of rice husk into silica ash after carbonization process is a potential source of pozzolanic that can be used as Supplementing Cementitious Material (SCM).

The use of RHA in combination with cement in appropriate mixture will produce a better cement composite (Singh, et al., 2002). RHA has been used as a highly reactive pozzolan material to recover the microstructure on interphase transition region between cement paste and aggregate. The utilization of rice husk ash as a pozzolanic material in cement and concrete provides several advantages, such as improved strength and durability properties, reduced materials costs due to cement savings, and environmental benefits related to the disposal of waste materials and to reduced carbon dioxide emissions (Bui, et al., 2005). Partial replacement of cement by $40 \%$ of RHA in the manufacture of mortar can generate good strength and resilience and also will reduce the cement usage, reduce greenhouse gas emissions, and increase the lifetime of the mortar (Chindaprasirt, et al., 2007).

Although Sarawasthy and Song (2007) recommends the use of RHA by $25 \%$ to create a composite of cement, but up to $30 \%$ is still able to 
reduce chloride penetration, reduce permeability, increase strength, and improve anti-rust properties of cement composites. Chindaprasirt, et al. (2008) found that the use of RHA in mortar is more resistant to chloride penetration than the mortar using palm oil fuel ash and fly ash. Replacement by $30 \%$ of RHA to cement has been used as SCM in manufacturing of high-strength concrete that has low permeability.

RHA is very fine particles having important role in the process of cement hydration. Hydration rate increases with decreasing particle size so that it can increase the strength of cement paste (Dermibas, 2004). Due to the smaller particle size than cement, RHA can serve as microfiller to increase the density of the cement composite (Nehdi, 2004). Amorphous silica of RHA has specific surface area ranging from 40 to $60 \mathrm{~m}^{2} / \mathrm{g}$ will react with $\mathrm{Ca}(\mathrm{OH})_{2}$ with the presence of water to form $\mathrm{CSH}$ at a temperature of $40^{\circ} \mathrm{C}$ (Yu, et al., 1999). Small particle size of RHA (less than 11 $\mu \mathrm{m})$ is a very reactive material and can be used to produce concrete having the compressive strength of $85 \mathrm{MPa}$ after 28 days curing period on the ratio RHA / (OPC + RHA) of 30\% (Sata, et al., 2007). Effect of RHA on various related parameters such as viscosity, rheology, plasticity, and elasticity depending on the particle size distribution, specific surface area, shape, and surface properties of RHA.

ASR mitigation can be conducted by (1) reducing the $\mathrm{pH}$ of the solution in the pores, (2) reduce the concentration of alkali metal ion (ion $\mathrm{Na}^{+}$and $\mathrm{K}^{+}$), and (3) reduce the permeability of cement paste (Lee, 2005).. Bertolini, L. et al. (2004) suggested that the use of blast furnace slag, fly ash, or silica fume as an SCM in a certain percentage can reduce the concentration of alkali ions on the cement so that reducing the $\mathrm{pH}$ below 13. The role of SCM has been shown the increase strength and durability of cement composites (Toutanji and Danson, 2001). Kerenidis (2007) argued that supplementary cementing materials are effective at mitigating ASR for multiple reasons. By replacing a portion of the cement with an SCM, or diluting the cement, there will be less cement present in the system resulting in a lower alkali content. Though some SCMs may themselves contain alkalis, it is to a much smaller extent than cement. SCMs also decrease the permeability of concrete, resulting from the more discontinuous pore structure achieved through their use. Lower permeability translates to a decreased rate of moisture and ion transfer into the structure. Finally, and possibly most importantly, SCMs are able to bind greater amounts of alkalis in their hydration products than ordinary PC alone. ASR that can not be controlled will cause cracks in concrete or other cement composite and reduce the strength and durability of concrete structures or composite cement.

MoDOT (2003) uses a variety of SCM such as fly ash, silica fume, and slag as to overcome ASR showing that concrete made without the SCM had medium permeability, the use of SCM for $15 \%$ and $25 \%$ had low permeability, and the use of SCM for $30 \%, 35 \%$, and $50 \%$ had very low permeability. Partial replacement of portland cement by SCM will reduce the free calcium hydroxide. SCM is derived from amorphous silica, such as RHA, will react with free calcium hydroxide faster than fly ash because the extremely high reactivity (Wang, et al., 2003). Hicks, (2007) recommended the reduction of water to cement ratio if using class $C$ fly ash to mitigate ASR

SCM effect on the ASR mechanism described by Freitag, et al. (2003) that (a) The total alkali content of the concrete will be reduced if the SCM has a lower alkali content than the cement it replaces. Not all the alkali in SCM is necessarily available to enter the pore solution, so the reactive alkali content of the concrete may be reduced even if the total alkali content is not, (b) Reaction of the SCM with the calcium hydroxide produced during cement hydration will reduce the calcium hydroxide available to maintain the very high $\mathrm{pH}$ necessary for ASR, (c) The product of the reaction between SCM and calcium hydroxide binds alkalis so that they are unavailable to participate in ASR. This retention is considered to be largely due to aluminum in the structure of the silicate reaction product, and (d) The concrete will be less permeable, reducing the ingress of moisture and the diffusion of alkalis to reactive minerals. The concrete may be stronger and better able to withstand expansive forces without cracking. Overall, these mechanisms cause the cement paste becomes less permeable and hence reducing the water to enter the alkali and reducing the diffusion of reactive minerals.

The use of RHA as SCM in OPC on a certain ratio can improve the properties of cement composites made. The specimens with silica extracted from rice husk showed higher compressive strength values when compared with 
their equivalent mixture without addition, already at the early ages. The reasons for early compressive strength development of concretes with RHA are due to fineness, amorphous phase, specific area and degree of reactivity of RHA (Silva, et al., 2008). Sandcrete block made by Oyetola and Abdollahi (2006) showed that the optimum replacement by RHA in the cement is $20 \%$ to produce a compressive strength of 36.5 $\mathrm{MPa}$ after 28 days curing period. Replacement of $20 \%$ RHA in cement mortar using natural sand produced mortar compressive strength of $54 \mathrm{MPa}$ after 28 days curing period (Chindaprasirt, et al., 2007). These research results prove that the use of RHA as a partial replacement of cement composites effectively increased the compressive strength of cement composite at the ratio of cement RHA (RHA/OPC + RHA) of $0.2(20 \%)$ in non-reactive rocks aggregate.

DTI (2003) explained that the use of the RHAIOPC up to $35 \%$ can achieve the maximum compressive strength while the use of the RHA / $\mathrm{OPC}+\mathrm{RHA}$ at $50 \%$ is still quite effective but the cement composite strength will be reduced after 28 days curing period. Ganesan, K., et al. (2008) revealed that $30 \%$ of cement replacement by RHA has no effect to the decreasing of mortar strength.. The use of RHA in the unreactive aggregate by Charoenvai, et al. (2005) showed that the addition of aggregate of durian fiber which contains most holosellulosa $(54.2 \%)$ in the mixed composition of cement: sand : durian bark fibers (1: $1: 0.1)$ yields the highest compressive strength at the RHA/OPC + RHA of $30 \%$ after 28 days curing settings. Research conducted by Hossain (2006) using reactive rock Scoria aggregate showed that the more Scoria used, the lower the compressive strength of lightweight concrete produced. Scoria is a light rock rich in silica $(45-50 \%)$ and classified as a reactive aggregate. Hossain (2006) suggested using fine particles Scoria as SCM in the manufacture of blended cement at $20 \%$ can be used to control the alkali silica reaction, while the use of Scoria up to $40 \%$ still meet the ASTM C 618 requirements.

\section{CONCLUSION}

Mortar Bar Test results proved that although the rice husk react in an environment with low alkali cement but still produce ASR that potentially damage the composite. The test also proved that the use of lime in cement mixture produced a smaller ASR gel, therefore use of lime in the cement mixture should be considered in making cement composite. Appropriate ratio of cement and lime can be introduced in producing the cement composite by considering the required physical and mechanical properties. It is need an intensive research to examine the best ratio of rice husk, cement, and lime to produce a high performance of the composite.The use of supplementing cementitious material (SCM) such a rice husk ash (RHA) can be mixed up into the ratio to mitigate the ASR gel of the composite.

\section{REFERENCES}

Bertolini, L., Elsener, B., Pedeferi, P., and Polder, R. P. 2004. Corrosion of Steel in Concrete. WILEY-VCH Verlag $\mathrm{GmbH}$ \& Co. KGaA. Weinheim, Germany.

Bui, D. D., Hu, J. and Stroeven, P. 2005. Particle Size Effect on the Strength of Rice Husk Ash Blended Gap-Graded Portland Cement Concrete. Cement \& Concrete Composites. 27: 357-366.

Charoenvai, S., Khedari, J., Hirunlabh, J., Daguenet, M., and Quenard, D. 2005. Impact of Rice Husk Ash on the Performance of Durian Fiberbased Construction Materials. Paper Presented on 10DBMC International Conference On Durability of Building Materials and Components. LYON (France), 17-20 April 2005.

Chindaprasirt, P., Kanchanda, P., Sathonsaowaphak, A., and Cao, H.T. 2007. Sulfate Resistance of Blended Cements Containing Fly Ash and Rice Husk Ash. Construction and Building Materials Journal. 21: 1356 - 1361.

Chindaprasirt, P. and Rukzon, S. 2008. Strength, porosity and corrosion resistance of ternary blend Portland cement, rice husk ash and fly ash mortar. Construction and Building Materials. 22: 1601-1606.

Demirbas, A. 2004. A discussion of the paper "Performance of Rice Husk Ash Produced Using a New Technology as a Mineral Admixture in Concrete". Cement and Concrete Research. 34: 1269. 
DTI. 2003. Rice Husk Ash Market Study. DTI/Pub URN 03/668. United Kingdom: Brozeoak Ltd (Contractor).

Folliard, K. J., Thomas, M. D. A., Fournier, B., Kurtis, K. E., Ideker, J. H. 2006. Interim Recommendations for the Use of Lithium to Mitigate or Prevent Alkali-Silica Reaction (ASR). Report No. FHWA-HRT-06-073. McLean, USA: Infrastructure Research and Development, Federal Highway Administration.

Freitag, S. A., Goguel, A. R., and Milestone, N. B. 2003. Minimizing the Risk of Damage to Concrete Guidance Notes and Recommended Practice (Second Edition). Technical Report 3 (TR 3). New Zealand: Cement and Concrete Association.

Ganesan, K., Rajagopal, K., and Thangavel, K. 2008. Rice husk ash blended cement: Assessment of Optimal Level of Replacement for Strength and Permeability Properties of Concrete. Construction and Building Materials. 22 (8): 1675 1683.

Hicks, J. K. 2007. Mitigation of Alkali-Silica Reaction while Using Highly Reactive Aggregates with Class C Fly Ash and Reduction in Water to Cementitious Ratio. Paper Presented on 2007 World of Coal Ash (WOCA), Covington, Kentucky, USA, May 7 - 10, 2007.

Hossain, K. M. A. 2006. Blended Cement and Lightweight Concrete Using Scoria: Mix Design, Strength, Durability and Heat Insulation Characteristics. International Journal of Physical Sciences. 1(1) : 005-016.

Kerenidis, K. 2007. Mitigating Alkali Silica Reaction in Concrete with Supplementary Cementing Materials when Used in Conjuction with Portland cements Having Alkali Contents in Excess of 1,0\%. PCA R\&D Serial No. 3023. Skokie, Illinois, USA: Portland Cement Association.

Lee, N. 2005. Alkali-Silica Reactivity in Concrete. New Zealand: Branz Ltd.

MoDOT. 2003. Laboratory Study- Laboratory Testing Of Bridge Deck Mixes. Report No. RDT03-004. Jefferson City, Missouri, USA: Department of Transportation Research, Development, and Technology.
Nehdi, M. 2004. A reply to the discussion by A. Demirbas of the Paper "Performance of Rice Husk Ash Produced Using a New Technology as a Mineral Admixture in Concrete". Cement and Concrete Research. 34:1271-1272.

Oyetola, E. B. and Abdullahi, M. 2006. The Use of Rice Husk Ash in Low - Cost Sandcrete Block Production. Leonardo Electronic Journal of Practices and Technologies. 8: 58 -70 .

Rangaraju, P. R. 2007. Mitigation of ASR in Presence of Pavement Deicing Chemicals. An IPRF Research Report. Innovative Pavement Research Foundation. Skokie, Illinois.

Singh, N.B., S. Rai, and S. Chaturvedi. 2002. Hydration of Composite Cement. Progress in Crystal Growth and Characterization of Materials. 171-174.

Saraswathy, V. and Song, Ha-Won. 2007. Corrosion Performance of Rice Husk Ash Blended Concrete. Construction and Building Materials. 21: 1779-1784.

Sata, V., Jaturapitakkul, C., and Kiattikomol, K. 2007. Influence of Pozzolan from Various byProduct Materials on Mechanical Properties of High-Strength Concrete. Construction and Building Materials. 21: 1589-1598.

Silva, F. G. da., Liborio, J. B. L., and Helene, P. 2008. Improvement of Physical and Chemical Properties of Concrete with Brazilian Silica Rice Husk (SRH). Revista Ingeniería de Construcción Journal. 23 (1): 18 - 25.

Toutanji, H. A. and Danson, A. D. 2001. Supplementary Cementitious Materials to Enhance Bridge Deck Durability. UTCA Report Number 00305. Tuscaloosa, Alabama, USA: University Transportation Center for Alabama.

Wang, L., Roy,. A., Seals, R. K., and Metcalf, J. B. 2003. Stabilization of Sulfate-Containing Soil by Cementitious Mixtures: Mechanical Properties. Paper Presented on TRB 2003 Annual Meeting.

Yu, Q., K. Sawayama, S. Sugita, M. Shoya and Y. Isojima. 1999. The Reaction between Rice Husk Ash and $\mathrm{Ca}(\mathrm{OH})_{2}$ Solution and the Nature of Its Product. Cement and Concrete Reaseach. 29: 37-43. 
Diterima : 12 Desember 2009

Bakri, Djamal Sanusi, and Musrizal Muin

Lab. Keteknikan dan Diversifikasi Produk Hasil Hutan

Fakultas Kehutanan Universitas Hasanuddin

Jl. Perintis Kemerdekaan Km. 10 Tamalanrea, Makassar 90245 